\title{
Estrogen Receptor Signaling and Its Relationship to Cytokines in Systemic Lupus Erythematosus
}

\author{
E. Kassi ${ }^{1,2}$ and P. Moutsatsou ${ }^{1}$ \\ ${ }^{1}$ Department of Biological Chemistry, Medical School, University of Athens, 75 M. Asias, Goudi, 11527 Athens, Greece \\ ${ }^{2}$ Laboratory of Clinical Biochemistry, "Attikon" University General Hospital, 1 Rimini, Haidari, 12462 Athens, Greece \\ Correspondence should be addressed to P. Moutsatsou,pmoutsatsou@med.uoa.gr
}

Received 15 January 2010; Revised 18 March 2010; Accepted 31 March 2010

Academic Editor: Brian Poole

Copyright (C) 2010 E. Kassi and P. Moutsatsou. This is an open access article distributed under the Creative Commons Attribution License, which permits unrestricted use, distribution, and reproduction in any medium, provided the original work is properly cited.

\begin{abstract}
Dysregulation of cytokines is among the main abnormalities in Systemic Lupus Erythematosus (SLE). However, although, estrogens, which are known to be involved in lupus disease, influence cytokine production, the underlying molecular mechanisms remain poorly defined. Recent evidence demonstrates the presence of estrogen receptor in various cell types of the immune system, while divergent effects of estrogens on the cytokine regulation are thought to be implicated. In this paper, we provide an overview of the current knowledge as to how estrogen-induced modulation of cytokine production in SLE is mediated by the estrogen receptor while simultaneously clarifying various aspects of estrogen receptor signaling in this disease. The estrogen receptor subtypes, their structure, and the mode of action of estrogens by gene activation and via extranuclear effects are briefly presented. Results regarding the possible correlation between estrogen receptor gene polymorphisms and quantitative changes in the receptor protein to SLE pathology and cytokine production are reviewed.
\end{abstract}

\section{Introduction}

Systemic lupus erythematosus (SLE) is a chronic autoimmune disease of unknown origin that affects several organ systems; diverse immunological abnormalities that are associated with this disease have been recognized both in human and in animal models with the most consistent being: (1) loss of B cell tolerance, (2) abnormal interactions between $\mathrm{T}$ and B cell signaling, (3) T, B cell and monocyte hyperactivity, (4) production of a wide range of pathogenic autoantibodies resulting from polyclonal $\mathrm{B}$ cell activation, and (5) defective clearance of autoantigens and immune complexes [1-3].

The key components of the immune system such as B and $\mathrm{T}$ lymphocytes, dendritic/macrophage cells, monocytes and thymus are involved in the underlying mechanisms of SLE, while an imbalance between Th-1 and Th-2 cytokine production plays a key role in the induction and development of the disease $[4,5]$. In particular, a switch from a type 1 (Th-1) to a type 2 (Th-2) T helper has been demonstrated where serum levels of Th-2 cytokines, such as interleukin IL4, IL-6, and IL-10, are elevated, while there is an observed decrease in production of Th- 1 cytokines, including IL-2 and interferon IFN- $\gamma[6,7]$. Among these cytokines, IL-10 seems to play a central role in the pathogenesis of SLE as well as in disease flare induction [8-10], while IL-6 has been identified as being a potent contributor to the differentiation of Th0 to Th-2 cells [11], its production increasing in patients with active disease [12]. Moreover, the elevation of TNF-a in the serum of SLE patients has been suggested as playing a role in the pathogenesis of the disease [13-15]. It is therefore apparent that soluble mediators of immune responses such as cytokines remain prime candidates for the pathogenic factors responsible for this systemic disease.

Although SLE still remains of unknown origin, a strong genetic predisposition has been recognized, this often being accompanied by environmental and hormonal factors that contribute to the expression of the disease. Among the above risk factors, female gender is considered to be the greatest [16]. The observed high female prevalence is most marked after puberty: while the pre-puberty female to male ratio is $3: 1$, this increases to $10: 1$ during the childbearing years and decreases again to $8: 1$ after menopause. 
Although estrogens have been proposed as obvious candidates to explain this sexual dimorphism [17], measurement of plasma estradiol levels did not reveal significant differences between normal women and women with SLE; nevertheless, abnormal levels of estrogenic metabolites have been identified in the latter. These metabolites include 2-hydroxyand 16-hydroxyestrone and their derivatives produced by the enzymatic oxidation of estrogen. Additionally, pregnancy is frequently associated with flares of the disease in SLE patients [17]. Of note, pregnancy can disturb the balance in favor of the highly feminizing 16-hydroxy metabolites, thus predisposing to SLE, while exercise or consuming specific foods that inhibit the $16 \alpha$-hydroxylase can have opposite effects [18]. The alternative metabolic pathway-the 2hydroxylation pathway-that leads to catechol estrogens has been found to be suppressed in SLE patients [19]. Administration of 17-beta estradiol $\left(\mathrm{E}_{2}\right)$ has also been observed to aggravate the disease in New Zealand brown/New Zealand white F1 female mice (a model of SLE) [20]. Interestingly, in lupus animal models, despite the elevated estrogen 2hydroxylase activity, abnormal formation of 2-hydroxylated and $16 \alpha$-hydroxylated products have not been demonstrated [21]. Moreover, Klienefelter syndrome, a XXY genetic syndrome characterized by an abnormal estrogen/androgen pattern resembling the female pattern, is associated with higher prevalence of SLE among men [22]. Concerning the role of hormone replacement therapy and oral contraceptive pills in the risk of developing and/or exacerbation of SLE, this issue still remains controversial [23-28]. It is of interest to note that, while studies in women using oral contraceptives versus those not using oral contraceptives demonstrated no significantly increased risk of developing SLE, by contrast, hormone replacement therapy in postmenopausal women seems to increase this risk [29]. Oral contraceptive use was not associated with changes in the disease course in premenopausal women with SLE, at least in the nonactive phase, but hormone replacement therapy increased the risk of mild flares in postmenopausal patients [30].

\section{Molecular Mechanisms of Estrogen Action}

2.1. Nuclear Actions. Estrogens exert their effects by activating their intracellular receptors, the estrogen receptor alpha $(\mathrm{ER} \alpha)$ and beta $(\mathrm{ER} \beta)$ isoform, encoded by their respective genes ESR1 and ESR2 [31,32]. These receptor proteins belong to the steroid receptor superfamily [33] and possess different sizes. Whereas ER $\alpha$ is comprised of 595 aminoacids, $\mathrm{ER} \beta$ is comprised of 530 (today known as ER $\beta 1$ long). It should be pointed out that the original human $\operatorname{ER} \beta$ clone encoded a protein of 485 aminoacids (today known as ER $\beta 1$ short). The ER $\beta 1$ long form is currently regarded as the fulllength wild type ER $\beta$ [34]. Their aminoacid sequences are organized as follows: the ligand binding domain located in the carboxyterminal region of the molecules, necessary for ligand binding; the DNA-binding domain, responsible for binding to specific DNA sequences (the Estrogen Response Elements, EREs); and the transcriptional regulation domain (AF-1), which is highly immunoreactive and is located in the aminoterminal part of the molecules. ER $\alpha$ and $\operatorname{ER} \beta$ exhibit high homology in their DNA binding domain (96\%), low homology (30\%) in their AF-1 domain and partial homology $(53 \%)$ in their ligand binding domain. Various ER $\alpha$ and ER $\beta$ isoforms and splicing variants (hER $\beta 1$ long, hER $\beta 1$ short, hER $\beta 2$, hER $\beta 4$, hER $\beta 5$, hER $\alpha$-46) have been described $[34,35] . \mathrm{ER} \alpha$ and $\mathrm{ER} \beta$ mediate their effects via regulation of transcription of target genes, directly or indirectly, liganddependently or ligand-independently. Hereinafter, the term ER refers to both $\mathrm{ER} \alpha$ and $\mathrm{ER} \beta$ subtypes.

In the absence of hormone, ER is bound to a multiprotein complex, including heat shock proteins, which render the receptor inactive. The ligand binding (endogenous estrogens or exogenous synthetic estrogen analogs) induces a conformational change to the receptor, which results in the release of bound accessory proteins, and promotes homodimerization of ER subtypes (ER $\alpha$ and $\mathrm{ER} \beta$ may homodimerize or heterodimerize) and high affinity binding to consensus EREs (AGGTCAnnnTGACCT) [36] located within the regulatory region of target genes [37].

The DNA bound receptors interact with many other coactivator proteins and negative coregulators/corepressors, resulting in the stabilization of a transcription preinitiation complex and the remodeling of chromatin and initiation of transcription by the basal transcriptional machinery and RNA polymerase [38-40]. Histone acetyltransferases (HATs) and histone deacetylases (HDACs) are key elements for the chromatin decompaction and initiation, such activities usually possessed by coactivator/corepressor protein complexes $[39,41,42]$. ER $\alpha$ and $\mathrm{ER} \beta$ may regulate gene transcription not only via direct binding to their consensus EREs but also by their interaction with other transcription factors such as the AP-1 (via protein-protein interactions) and modulation of the binding of AP-1 to AP-1 binding sites onto DNA (AP-1 responsive elements), thus regulating AP-1 depending gene transcription [43]. ER $\alpha$ and ER $\beta$ respond differently to certain ligands in stimulating the ERE or AP-1 pathway [44]. For example, tamoxifen is a strong agonist of AP-1 dependent transcription in certain tissues (uterus, endometrium), promoting growth, while it acts as an antiestrogen via the classical EREs, in breast cancer tissue [45]. Similarly, estrogen receptor may interact with NF- $\kappa \mathrm{B}$ (via proteinprotein interactions), resulting in modulation of the binding of NF- $\kappa \mathrm{B}$ to NF- $\kappa \mathrm{B}$ binding sites on the DNA (NF- $\kappa \mathrm{B}$ response elements), thus regulating NF- $\kappa \mathrm{B}$ dependent gene transcription. The estrogen receptor regulates NF- $\kappa \mathrm{B}$ mediated gene expression in a cell-type-specific manner and has important implications in inflammatory processes $[46,47]$.

Extracellular signals such as insulin, IGF-1, EGF, and TGF- $\beta$, phosphorylate $\mathrm{ER} \alpha$ and $\mathrm{ER} \beta$ (in the AF- 1 region) via the mitogen activated protein kinases (MAPKs) in the absence of ligand, resulting in transactivation of the receptors and initiation of ERE-mediated gene expression [48]. Phosphorylation is a posttranslational modification of ERs on serine and tyrosine residues. Cellular enzymes such as kinases and phosphatases transfer a phosphate group from ATP onto target proteins or remove it, respectively. Estrogens as well as extracellular signals and regulators of the general cellular phosphorylation state (e.g. protein kinase A, protein kinase C, cyclin dependent kinases) [49] phosphorylate ERs, 
thus affecting ER functions, positively or negatively, such as transcriptional activity, stability and nucleocytoplasmic shuttling. Estradiol, cell cycle regulators, the enzymes PKA, PKC, extracellular signals such as growth factors, cytokines and neurotransmitters phosphorylate human ER $\alpha$ at serine residues in the aminoterminal A/B domain (serine-104, $-106,-118,-154,-167)$. Phosphorylation sites at serines in DBD, hinge region, and LBD (ser-236, -294, -305) have also been identified. Phosphorylation at ser-118 in human ER $\alpha$ is considered the consensus phosphorylation site for MAPKs and potentiates the interaction with coactivators, while phosphorylation of tyr-537 regulates ER $\alpha$ ligand binding. All together, the ER-mediated signaling cascade, that is, ligand binding, dimerization, DNA binding and interaction with cellular cofactors, seems to be regulated by phosphorylation of $\operatorname{ER} \alpha$ (summarized in [50]). Studies on ER $\beta$ phosphorylation suggest that ser-106 and ser-94 phosphorylation sites at the $\mathrm{A} / \mathrm{B}$ domain modulate subnuclear mobility of the receptor, the ER $\beta$ cellular levels, indicating thus that these phosphorylated serine residues generate signals to the ubiquitin proteasome pathway [51]. Phosphorylation at ser-106 and ser-124 also enhance the interaction with the coactivator SRC-1. Phosphorylation at ser- 87 has been identified as a regulator of ER-dependent gene expression and growth of breast cancer cells [52]. Collectively, in the presence of diverse physiological signals other than their cognate ligand, the ERs may be activated, this accompanied by an increased phosphorylation state, a pathway which may be responsible for tissue-specific responses, especially in cases where the concentration of these extracellular signals (e.g., growth factors) is locally increased and estrogens are too low.

\subsection{Extranuclear Actions}

2.2.1. Plasma Membrane ER. Studies demonstrating that estrogens can cause effects too fast to be based on transcriptional events led to the identification of membrane estrogen receptors responsible for non-genomic responses. The estrogen receptor membrane form exists as a fulllength ER, as an isoform, or as a distinct receptor [53-55]. Membrane forms for both $\operatorname{ER} \alpha$ and $\operatorname{ER} \beta$ have been identified [56]. The membrane localization of ER has been shown to be mediated by the adaptor protein Shc and insulin-like growth factor I receptor [57], while interaction with caveolin-1 and palmitoylation occurring on a specific cysteine (C447) ER residue also plays an important role in this localization $[57,58]$.

Accumulated evidence strongly supports the importance of plasma membrane estrogen receptors in a variety of cells. GPR30, a G protein-coupled receptor (GPCR), binds $\mathrm{E}_{2}$ with high affinity and generates rapid effects $[58,59]$, including stimulating $\mathrm{Ca}^{2+}$ mobilization from intracellular stores directly or via epidermal growth factor receptor (EGFR) transactivation, c-fos expression, adenyl cyclase, and cAMP mediated signaling and ERK-1/2 in a variety of cell types [60].

Additional signal transduction pathways that are rapidly responsive to $E_{2}$ and originate from the membrane involve the stimulation/inhibition (being dependent on the ER $\alpha$ or ER $\beta$ subtype) of phosphoinositol-3hydroxy kinase (PI3K) and the family of MAP kinases, such as extracellularregulated kinase (ERK), p38 $\beta$ isoform, as well as the c-Jun $\mathrm{N}$-terminal kinase (JNK) [61]. Indeed, $\mathrm{E}_{2}$ has been shown to bind the transmembrane G-protein-coupled receptor homolog GPR30 and to activate p44/42 MAPK through transactivation of EGFR [62, 63]. Of note, the signaling from the membrane can also extend to other intracellular transcription factors such as AP- 1 or NF-kB, resulting in gene repression or activation.

The non-genomic actions of estrogens seem to be implicated in important functions such as cell growth, proliferation, differentiation and apoptosis of various cell types (endothelial, bone, neuronal cells, etc.). With regard to the immune system, there are studies confirming the presence of the membrane ER $\alpha$ receptor in peripheral blood mononuclear cells (PBMCs), with estradiol inducing NO release and calcium flux through binding to this receptor. It is of interest that the presence of tamoxifen did not antagonize this effect [64]. Moreover, estradiol acting in human monocytes induced the rapid release of NO through membrane ER $\alpha$ and/or ER $\beta$ [64]. Benten et al. [65] confirmed the existence of membrane ER in T-cells; according to their study, binding of estradiol to membrane ER resulted in release of NO, an effect that was not abolished by the presence of tamoxifen.

2.2.2. Mitochondrial ER. Accumulating evidence has demonstrated that estrogens exert substantial effects on mitochondrial function, some of these effects being the following: (a) estrogens are potent stabilizers of ATP production during oxidative stress, while under basal conditions they show little effect on mitochondrial ATP production; (b) estrogens prevent $\mathrm{Ca}++$ influx into mitochondria under high excitotoxic stimulation; (c) estrogens protect mitochondria by preventing mitochondrial membrane potential collapse [66]. More importantly, $\mathrm{E}_{2}$ —regulates the expression of mtDNAencoded respiratory chain subunits such as cytochrome oxidase subunits I, II, III in various cell types/tissue [67-69].

Several laboratories have reported the localization of ER $\alpha$ and ER $\beta$ in mitochondria in various target cells and tissues by a variety of techniques such as immunohistochemistry, immunocytochemistry, and immunoblots using a wide range of antibodies. A number of studies have demonstrated the presence of $\mathrm{ER} \alpha$ in mitochondria of female rat cerebral blood vessels, MCF-7 cells, HepG2 cells, and the $2 \mathrm{C} 12$ murine skeletal muscle cell line. Accumulating evidence supports the presence of $\operatorname{ER} \beta$ in the mitochondria in rabbit uterus and ovary, in MCF-7 cells, in endothelial cells, in primary neurons, primary cardiomyocytes, murine hippocampus cell lines and human heart cells, in human lens epithelial cells, human liver cancer HepG2 cells, osteosarcoma SaOS2 , sperm, and periodontal ligament cells $[66,70]$. The localization of ER $\beta$ in mitochondria has also been verified by proteomics. It should be noted that the wild type human $\operatorname{ER} \beta$ (known as $\operatorname{ER} \beta 1$ ), and not the isoforms $\operatorname{ER} \beta 2$ to $\operatorname{ER} \beta 5$, is preferentially localized in the mitochondria $[66,70]$.

It is noteworthy that sequences showing partial similarity to ERE consensus sequence have been detected in the D-Loop 
region, the major regulatory region of the mitochondrial genome $[71,72]$. Several lines of evidence have demonstrated that $\operatorname{ER} \alpha$ and $\operatorname{ER} \beta$ exhibit specific binding to these mtEREs [73], while the mitochondrial ER $\beta$ in immortalized human breast epithelial cells (contain ER $\beta$ only) has been directly associated with E2-induced expression of mtDNA-encoded respiration chain subunits (COXI, COXII of complex IV and ND1 of complex I) [74]. Collectively, the above data support the hypothesis that the mitochondrial genome may be a primary site of action of estrogens [71].

It is important to mention that an elevation of the mitochondrial transmembrane potential and ATP depletion has been observed in circulating lymphocytes of patients with SLE [75, 76]. Moreover, lupus T cells overexpress genes involved in mitochondrial electron transport [77], whereas a borderline association at nt4917 of the ND2 gene (complex I) and a significant association of the variant at nt9055 in the ATP6 or F0F1-ATPase gene (complex V) have been demonstrated in SLE patients [78]. The above data imply that the estrogen-mitochondria crosstalk may be of importance in the pathophysiology of SLE disease.

\section{Estrogen Signaling and the Regulation of Cytokines in Immune Cells}

Given the central role of estrogens in stimulating SLE disease and because cytokines are substantially involved in the pathogenesis of SLE, we herein provide evidence elucidating the molecular basis of the interplay between estrogen and cytokines in immune cells/organs known to be of crucial importance in the control of the autoimmune response. Because estrogens mediate their effects via estrogen receptors (nuclear isoforms and/or membrane receptor), studies have focused on the detection of the above receptors in the immune cells ( $\mathrm{B}$ cell, $\mathrm{T}$ cells, dendritic/macrophages, monocytes) as well as in the immune organs (thymus) and their possible role in autoimmunity [79].

The thymus is an immune organ of prime importance since it is well known that CD4+ and CD8+ $\mathrm{T}$ cell development is a result of a complex process, starting with the migration of progenitors from bone marrow to the thymus and followed by positive and negative selection processes that are critical for both final maturation of $\mathrm{T}$ cells and prevention of autoreactivity [80]. The loss of thymus function, after ablation of a hyperplastic thymus has been shown to contribute to the development of SLE [81]. Moreover, the MRL/lpr strain (an SLE mouse model) develops early in life autoimmune diseases characterized by thymic atrophy [82]. Firstly, Stimson and Hunter [83] demonstrated estrogen receptors in the human thymocytes. Estrogen has been shown to lead to thymic atrophy through various mechanisms including, among others, modulation of the production of $\mathrm{IL}-7$, an important regulator of Tlymphopoiesis [84]. It is of import to bear in mind, the presence of both $\operatorname{ER} \alpha$ and $\operatorname{ER} \beta$ is required to exert this action, while in mice it has been demonstrated that ER $\alpha$ needs to be expressed in both the hematopoietic and stromal compartments of the thymus [85]; on the other hand, the achievement of a full-sized thymus requires the presence of $\mathrm{ER} \alpha$ in stromal but not in thymic cells [85].

Additionally to the $\mathrm{T}$ cell development, estrogen has been shown to exert important effects on $\mathrm{T}$ cell function through ERs which have been identified in both CD4+ and CD8+ T cells $[86,87]$ in a biphasic way. As already mentioned, that SLE is characterized by a shift from the balance between Th1 and Th-2 subsets to Th-2 dominance. It is well known that low doses of estrogen promote enhanced $\mathrm{Th}-1$ responses and increased cell-mediated immunity, while high doses of estrogen lead instead to increased Th-2 responses [88, 89]. Of note, the enhancement of Th-1 responses to low-dose estrogen required the presence of $\operatorname{ER} \alpha$, but not $\operatorname{ER} \beta$ [88]. The high estrogen levels that accompany pregnancy may account for the stronger humoral responses and possibly contribute to the flares that some SLE patients experience during pregnancy $[90,91]$. This effect of estrogens seems to be achieved through direct alteration in the Th cytokine profile from a proinflammatory (IL-2, IFN- $\gamma$, TNF-a) to an anti-inflammatory direction ( IL-4, IL-6, IL-10, TGF- $\beta$ ) [92]. Indeed, $\mathrm{E}_{2}$ as well as estrone and estriol have been shown to stimulate IL-10 in human CD4+ cells $[30,93,94]$, while their effect on antigen-stimulated secretion of TNF-a was biphasic, with enhancement at low concentrations and inhibition at high concentrations [93]. A stimulatory effect of estriol on IL-10 production, in contrast to the inhibitory effect on TNF-a, has also been revealed by Zang and coworkers [95]. Lambert et al. [96], in agreement with previous studies $[97,98]$, observed a significant $\mathrm{E}_{2}$ induction of IL-4 secretion by purified CD $4+\mathrm{T}$ cells, an effect mediated through $\mathrm{ER} \alpha$ in a classical ligand-dependent manner. IL-2, another cytokine important for differentiation of $\mathrm{T}$ cell responses into Th-1 or Th-2 predominance, has been found to be suppressed by high concentrations of estradiol in activated peripheral blood $\mathrm{T}$ cells and CD4+ T cell lines [99].

A recent and highly interesting study by Xia et al. [100] showed that estrogen replacement therapy increased the IL4 while decreasing IL-2 and IFN- $\gamma$ secretion by $\mathrm{T}$ cells isolated from surgically induced menopausal women, an effect which seems to be mediated mainly through ER $\alpha$. An $\mathrm{ER} \alpha$-mediated regulation of IL- 2 and IFN- $\gamma$ secretion is also exhibited in splenic T cells [101]. Other cytokines, like IL12 which is a central stimulator of Th1 type cytokines [102], as well as IL-1, are also influenced by estrogen action in $\mathrm{T}$ cells, with divergent results $[89,103]$. IL-17 is a novel cytokine derived from $\mathrm{T}$ cells which has been shown to play an important role in the Th-1/Th-2 balance [104] and has recently been implicated in the pathogenesis of SLE [105]. A recent study showed that estradiol reduces the production of IL-17 by upregulation of PD-1 (programmed death 1) expression within the Treg-cell compartment, an effect mediated through membrane ER [106, 107]. With respect to IL-6, most studies, albeit conducted in PBMC or whole blood cultures which include multiple cellular components, demonstrated an inhibitory effect of estrogen [108, 109].

Many studies have shown that estrogens regulate the cytokine gene expression in different cell types, via ERmediated pathways, either directly through EREs or indirectly through interaction of ER with other transcription 
factors including NF-kB and AP-1 $[43,46]$. EREs have been recognized in the promoter of IFN- $\gamma$ and IL-10 genes [110, 111]. It is of note that NF-kB response elements have also been found in the promoter of several cytokine genes like IL-6, IL-10, TNF-a IL-1 $\beta$, IL-12, and IL-2 [112-114], while there are cytokines, that can be transcriptionally regulated through interaction of more than one transcription factor. Indeed, IL-2 is tightly controlled by several transcription factors that bind to the IL-2 promoter; these transcription enhancers include NFAT, NF-kB, and AP-1, while there is evidence that all binding sites on the IL-2 promoter need to be occupied to ensure maximal transcritption and production of IL-2 [114, 115]. Disturbances in the transcriptionally active proteins, including NFAT (nuclear factor of activated T cells), members of the AP-1 (c-Fos, cJun), and NF-kB (c-rel, p50, p65) families, have been shown to modulate cytokine gene expression in activated $\mathrm{T}$ cells $[112,114,116,117]$. Importantly, abnormal NF-kB signaling characterized by decreased p65-RelA, increased c-rel and reduced NF-kB DNA binding activity, associated with altered cytokine expression, has been recognized in T cells from SLE patients [118-121]. Similarly, disturbances in AP-1-signaling associated with alterations in c-fos protein expression and AP-1 DNA binding activity has also been demonstrated in T cells from SLE patients [122-124].

The question now arises: how the estrogen-estrogen receptor pathway cross-react with NF-kB and/or AP-1 mediated signaling in lymphocytes to regulate cytokine gene expression? Mechanistic studies on the direct interaction between ER and NF-kB/AP-1 in immune cells, which is presumed important in the control of estrogen-induced immune responses and cytokine expression, are only sparse. Zang et al. [95] were the first to reveal that estriol altered cytokine profile of human normal $\mathrm{T}$ cells through inhibition of IkBa degradation [95]; interestingly, this effect was specific for NF-kB and not for other transcription factors like AP-1, and was ER-mediated, since it was partially abolished in the presence of tamoxifen $[118,119]$. However, a recent study has demonstrated that $\mathrm{E}_{2}$, acting through $\mathrm{ER} \beta$, could directly enhance NF-kB activity in human T cells, suggesting that estrogen actions on NF-kB activity may depend on ER and cell subtypes [125]. An enhanced transcriptional activity of nuclear NF-kB p65 in macrophages from $\mathrm{E}_{2}$-treated mice was also observed by Calippe et al. [126]; according to their results, this enhanced NF-kB activation could be a consequence of the reduced PI3K activity, as a result of chronic exposure to estrogens, through direct or indirect mechanisms, a hypothesis, however, which remains to be elucidated.

Apart from T-cells, monocyte-derived dendritic cells are substantially involved in the pathogenesis in SLE. Dysfunctional dendritic cells in human SLE have been described. In studies describing dysfunctional dendritic cells in human SLE [127, 128], monocyte-derived dendritic cells from lupus patients displayed an abnormal phenotype characterized by accelerated differentiation, maturation, and secretion of proinflammatory cytokines, suggesting that they are in a preactivated state. Interesting effects of estrogens on the function as well as cytokine secretion by dendritic cells and monocyte/macrophage have been demonstrated. Indeed, Douin-Echinard et al. confirmed that estrogens are required to generate optimal numbers of fully functional dendritic cells in vitro, while they induce secretion of IL- 6 and IL-12; of note, these effects of $\mathrm{E}_{2}$ were dependent on $\mathrm{ER} \alpha$ and not $\mathrm{ER} \beta$ [129]. $E_{2}$ increased the B cell-stimulating IL-10 production by monocytes [130]. Moreover, estrogen can enhance release of IL-6, TNF-a and interleukin-1 (IL-1), from human activated monocytes and/or macrophages, through modulation of CD16 expression [131], although other pathways not involving CD16, whether or not ER-mediated, have previously been recognized [132-134]. At the same line, $\mathrm{E}_{2}$ was found to increase TNF-a, IL-6, and TGF- $\beta$ secretion by differentiated monocyte/macrophages [135]. It should be noted that in regard to TNF-a and IL- $1 \beta$, the existing literature is at present inconsistent, with $\mathrm{E}_{2}$ either enhancing or inhibiting their secretion by macrophages/monocytes [30]. The divergent results concerning the estrogen effect on the expression of various cytokines would seem to be attributable to differences in the cell type, in concentrations of $\mathrm{E}_{2}$, in type of experiment (in vivo or in vitro) as well as in duration (shortterm vs longterm) of $E_{2}$ exposure. In support of the latter, Calippe et al. [126] exhibited the fact that chronic in vivo $\mathrm{E}_{2}$ administration promotes the expression of IL-1 $\beta$, IL-6, IL-12p40 by macrophages in response to TLR4 activation, whilst short-term in vitro exposure in $\mathrm{E}_{2}$ decreased the expression of these inflammatory mediators.

All the above data strongly suggest that estrogens by acting via their receptors and their crosstalk with other transcription factors in immune cells and organs can modulate immunological parameters and processes that have been shown to be implicated in the pathogenesis of SLE.

\section{Estrogen Signaling and the Regulation of Cytokines in SLE}

Numerous disorders of the immune system and abnormalities in cytokine production have been described in patients with SLE. Although there is much indirect evidence for estrogen involvement in the lupus disease process, the direct role of estrogen/estrogen receptor-mediated pathways in regulating cytokine production in SLE patients has not as yet been clearly defined.

Pursuing the same line of research, Evans et al. [136] set out to investigate the effect of estrogen on spontaneous in vitro apoptosis of PBMCs and T cells from women with SLE. Although their data did not allow of any conclusion as to which cell type was predominantly affected by estrogen, nor whether this was a direct or an indirect effect, they nevertheless found that there was an estrogen-induced decrease in apoptosis combined with decreased TNF-a production in the presence of estrogens which could probably enable survival of autoimmune cells in SLE patients. In the same study, estrogen-induced production of other cytokines, like IFN- $\gamma$ or IL-1 $\beta$, by PBMCs was not significantly different between normal and SLE cell cultures.

However, the first evidence for a molecular marker of estrogen action in lupus patients was provided by Rider et 
al. [137], who suggested that estrogen-dependent changes in lupus $\mathrm{T}$ cell calcineurin could alter proinflammatory cytokine gene regulation and T-B cell interactions. Indeed, application of RNase protection assays revealed increased calcineurin expression in response to exogenous $E_{2}$ in cultured $\mathrm{T}$ cells from female lupus patients. Calcineurin is known to stimulate dephosphorylation of substrates such as nuclear factor of activated T cells (NFAT), resulting in transactivation of target genes, including IL-2 [138, 139]. NFAT is a transcription factor that forms a complex with Fos and Jun proteins in the nucleus of activated $\mathrm{T}$ cells. Dephosphorylation by calcineurin translocates NFAT from the cytoplasm to the nucleus, where it binds promoter sequences and activates IL-2 transcription $[140,141]$ as well as the CD40Ligand (CD40L) [142]. It should be mentioned that CD40L plays a central role in pathogenic humoral immune responses in SLE, providing contact-dependent Th signals for B cell production of class-switched antibodies [143-145].

Other transcriptional regulators that may be controlled indirectly by calcineurin include the NF-kB (NF-kB)/Rel proteins [146]. Rider et al., in seeking to delineate the molecular mechanisms involved in estrogen control of calcineurin [137], demonstrated that the estrogen-dependent increase in intracellular calcineurin mRNA and its activity is a direct effect, mediated through ER.The same research group established that 2-fluoro- $\mathrm{E}_{2}$ exerted a significant increase in the amount of CD40L in peripheral blood T cells from SLE patients, which was blocked by ICI 182780 (thus implying a ER-mediated action) [147]. Extending their research ten years later, they demonstrated that by blocking estrogen receptors in vivo by an estrogen selective receptor downregulator (fulvestrant) in SLE premenopausal women, they reduced significantly the expression of calcineurin and CD40L (CD154) mRNA in peripheral T cells [148].

In 2001, another research group [149] examined whether changes in the cytokine milieu of SLE patients were associated with serum sex hormone levels. According to their results, SLE patients were characterized by higher levels of endogenous serum $\mathrm{E}_{2}$; however, the observed abnormalities in the cytokine milieu did not correlate with the abnormal $\mathrm{E}_{2}$ serum levels, suggesting that increased $\mathrm{E}_{2}$ may induce cytokine abnormalities only early in the disease, without being implicated subsequently.

Given that SLE is considered to be a Th-2 cytokinedriven disease, while pregnancy is also a condition in which the cytokine environment is predominantly Th2 polarized, with an enhancement of antibody-mediated immune responses, Doria et al. [150] decided to evaluate levels of selected cytokines in the humoral immune response during pregnancy in SLE patients. Notably, they found high serum levels of IL-10 in SLE patients either before or during pregnancy, thereby supporting the view that IL-10 overproduction in SLE is mainly constitutive rather than modulated by estradiol. By contrast, in the same study IL6 serum levels in SLE women reflected the levels of $E_{2}$ during the three trimesters of pregnancy, thus suggesting its regulation by estrogen. Apart from the abovementioned studies focused on direct effects of $E_{2}$ on the cytokine production in SLE, a very recent study [151] investigated in PBMC of SLE patients the interaction among cytokines and estradiol on the regulation of immune-response related molecules; interestingly, using DNA microarrays analysis, they failed to reveal any functional interaction between estradiol and IFN-a on the expression of interferon-inducible genes in SLE.

A sex-related expression of the disease, similar to that in man, is known to occur in several animal models of autoimmune diseases. In many genetic based murine models of lupus, including NZB/NZW F1 and MRL/lpr/lpr mice, the females also develop more severe disease and higher titers of autoantibodies at an earlier age $[152,153]$, while estrogen supplementation is associated with worsening disease and accelerated mortality. Supporting the direct implication of estrogen in the development and the course of experimental murine SLE, Sthoeger et al. [154] demonstrated therapeutic effects of tamoxifen (selective estrogen receptor modulator), while three years later the same group [155] suggested that these beneficial effects were associated with cytokine modulations; indeed, treatment with tamoxifen restored the levels of IL-2, IL-4, IFN- $\gamma$, TNF-a, and IL-1 to the normal levels observed in control mice, thus implying an estrogen receptor-mediated effect. High levels of serum estrogen have been associated with decreased IL-2 production in $\mathrm{NZB} / \mathrm{NZW}$ mice [156], while $\mathrm{E}_{2}$ treatment has been shown to result in increased serum TNF-a and IL-6 levels following LPS challenge in normal as well as in MRL/lpr/lpr mice; these changes were also blocked by tamoxifen [157].

\section{ER and SLE}

In 1986, Weusten et al. [158], following the detection of estrogen receptors in thymocytes and peripheral blood monocytes of SLE patients, for the first time proposed the possibility of an ER implication in the pathogenesis of SLE. At the same time, Kelly and Vertosick [159] suggested the hypothesis of a potential role of ER as an autoantigen in SLE; according to this hypothesis, the proposed target of autoimmune attack, i.e. the estrogen receptor normally resident in the nucleus, is physiologically more highly activated in women, while autoantigenicity of ER is enhanced in SLE patients owing to an abnormality of estrogen metabolism leading to metabolite-derivatives which favor ligand occupancy of the receptor.

Thereafter, numerous studies have been carried out specifically to identify quantitative and qualitative differences in estrogen receptor(s) related to SLE disease, to Th-1 and Th-2 cytokine expression as well as to clinical characteristics like age onset, clinical symptoms, and disease activity, all, however, with conflicting results. Indeed, Athreya et al. [160] as well as Suenaga et al. [161], studying PBMC and monocytes, did not find significant differences in the number of estrogen receptors, nor in their binding affinity, between SLE patients and normal women, while Feng [162] revealed differences related to the disease activity.

Since ER $\alpha$ splicing variants lacking specific functional domains have been found in human estrogen-responsive tissues and have been previously implicated in diseases 
of estrogen-dependent tissues/cells, by affecting estrogen action, the expectation was that attention would be focused on the identification of possible differences in expression of such ER $\alpha$ splicing variants by immune cells and their correlation with SLE. Although Wilson et al. [163] suggested that the presence of ER splice variant with deletion of exon 5 (DER5) in PBMC was causally related to SLE, experimental results from our laboratory [164], in agreement with those provided by Suenaga et al. [87], have shown that patients affected by SLE expressed in their peripheral blood T cells, monocytes, and B-cell lines wild type ER $\alpha$, DER5, and DER7 transcripts as did healthy individuals.

Since its first identification $[32,165], E R \beta$ has continued to be of particular interest as it is highly expressed in tissues related to the immune system, potentially implying that some of the immunomodulatory effects of estrogens might be mediated by this receptor form. Several studies have demonstrated that monocytes and lymphocytes express both $\operatorname{ER} \alpha$ and $\operatorname{ER} \beta[50,164,166]$, while quantitative differences in the expression of ER $\alpha$ and ER $\beta$ mRNA have been observed among cell populations such as T cells, B cells and monocytes as assessed by Real Time Quantitative PCR (RQ$\mathrm{PCR})$. Indeed, CD4+ T cells have been found to express relatively high levels of ER $\alpha$ mRNA compared with ER $\beta$ mRNA, whereas B cells expressed high levels of ER $\beta$ mRNA and low levels of ER $\alpha$ mRNA [50, 166]. Additionally, in the same study by Phiel et al. [166], CD8+ T cells and monocytes expressed comparably low levels of both ERs. Recently, proceeding in the same line of research, Xia et al. found that both $\operatorname{ER} \alpha$ and $\operatorname{ER} \beta$ were expressed on T cells of surgically induced menopausal women, with the expression of ER $\alpha$ being higher than that of ER $\beta$ [100]. At mRNA level, both ER $\alpha$ and ER $\beta$ are expressed by PBMC, as well as by $\mathrm{T}$ cells isolated from lupus patients [137, 164]. However, a recent study [167] conducted on PBMC of SLE patients has demonstrated increased expression of ER $\alpha$ mRNA and decreased expression of ER $\beta$ mRNA compared with PBMC from normal controls. Interestingly, the highest expression of $\mathrm{ER} \alpha$ was observed in $\mathrm{CD} 4+$ and $\mathrm{CD} 8+\mathrm{T}$ cells from SLE patients, whereas ER mRNA expression by $B$ cells from SLE patients was decreased compared with normal B cells; regarding ER $\beta$, a significant inverse correlation between ER $\beta$ mRNA expression and the SLEDAI score was discerned. In contrast, Rider et al. [168] found that the expression of ER $\alpha$ or ER $\beta$, as estimated by immunoblotting, was independent of SLE disease activity, while both ER $\alpha$ and $\operatorname{ER} \beta$ agonists increased calcineurin and CD40L expression in SLE T cells but not in normal $\mathrm{T}$ cells. It is of interest to note that, although the amount of ER $\alpha$ appeared to be less in SLE T cells than in control $\mathrm{T}$ cells, this receptor subtype participated more than ER $\beta$ in the sensitivity of SLE T cells to estrogen. These results, although in need of further clarification, are indicative of a possible stronger influence of estrogen on $\mathrm{T}$ cells, mediated mainly through ER $\alpha$ in SLE patients.

It must be mentioned here that mRNA expression is not always correlated with expression at the protein level or with the number of functional ERs simply because posttranscriptional modification of this receptor has been shown to occur; this could offer a possible explanation for the conflicting results observed during the quantitative evaluation of ER $\alpha$ and ER $\beta$ in immune cells [169].

Polymorphisms occur frequently throughout the human genome and in some cases are known to alter either the expression or the function of a gene product [170]. Several studies have demonstrated the presence of a variety of estrogen receptor polymorphisms and their association with various diseases, among them SLE. Results from our laboratory indicated that the estrogen receptor alpha codon 594 genotype may influence the development of SLE at a younger age, as well as a specific disease clinical pattern, while another two ER $\alpha$ polymorphisms in exon 1 (codon 10 and codon 87) were not associated with the disease [171]. Other studies have shown that PvuII and XbaI polymorphisms (intron 1 of ER $\alpha$ ) were associated with a milder form of SLE characterized by skin manifestations, less organ damage as well as with early onset of the disease $[172,173]$. In the same line, a previous study by Liu et al. [174] associated the PpXx genotype with a higher frequency of skin rashes and arthritis in SLE patients, while hematological abnormalities and hypertension were more severe in patients with ppxx, and renal vasculitis and interstitial injury in those with Ppxx genotype. Moreover, the PpXx genotype of the ER gene was associated with the susceptibility of SLE in the male but not in the female. A very recent study conducted an interesting analysis of the relationship between estrogen receptor polymorphisms and the Th1 and Th2 cytokine expression in patients with SLE. According to their results, Pvu II and XbaI polymorphisms are associated with an alteration in the Th-1/Th-2 balance in favor of Th-2, increasing the susceptibility to SLE. The findings indicated that ER $\alpha$ gene polymorphisms could influence the expression of IL-10, IL-4, IL-2 and IFN- $\gamma$ in SLE, with the Th-2 cell being predominant in patients with PpXx and Ppxx genotypes [175]. Finally, another recent study determined the impact of estrogen receptor null genotypes on disease in NZM2410, and MRL/lpr mice, as a method to define the role of estrogen receptor signaling in lupus. Their data demonstrated a key role of ER $\alpha$, but not $\mathrm{ER} \beta$, in the development of lupus-like disease in female NZM and MRL/lpr mice [176].

\section{Conclusion}

SLE is characterized by numerous immune system disturbances including alterations in cytokine regulation. Estrogens are known modulators of immune system functions, influence cytokine production and are involved in the lupus disease process. Accumulating evidence on the molecular and cellular actions of estrogens via the estrogen receptor subtypes $\operatorname{ER} \alpha$ and $\operatorname{ER} \beta$ adds to the depth of our understanding of estrogen-estrogen receptor mediated signaling. Both estrogen receptor proteins have been detected in immune cells, while increasing information points to their possible involvement in cytokine expression. However, in spite of the clinical significance of the estrogen-induced changes in cytokine production in SLE disease, many of the key elements in the underlying molecular mechanisms remain largely unknown. Existing data show an estrogen receptor-mediated effect in the production of cytokines and other cytokine 
regulatory molecules (such as calcineurin and $\mathrm{CD} 40 \mathrm{~L}$ ) in humans and animal models of SLE disease. A possible correlation of ER gene polymorphisms and of quantitative and qualitative changes in the receptor proteins to cytokine production and to disease aetiopathogenesis have also been reported. Clearly, further elucidation of ER signaling in SLE awaits characterization of the interactions of ER with the many other intracellular molecules and/or its interplay with other signaling pathways.

Recent evidence indicates a role of estrogens in mitochondrial function in immune cells along with cytokine regulation, while the existence of mitochondrial ER in human cells has been associated with stimulation of mitochondrial encoded enzymes. The above data, together with the recent findings that SLE patients are characterized by mitochondrial dysfunction, suggest that novel pathways of the estrogenER complex in mitochondria in immune cells may play a key role in SLE. The use of gene and/or protein expression profiling by microarray technology as well as the application of other molecular biology techniques in elucidating the underlying mechanisms will provide valuable information about the "signature" of the ER-regulated cytokine profile that are highly likely to be helpful in the design of future therapeutic strategies.

\section{Acknowledgment}

The authors express warm thanks for the Special Account for Research Grants of the National and Kapodistrian University of Athens.

\section{References}

[1] J. Zhang, A. M. Jacobi, T. Wang, R. Berlin, B. T. Volpe, and B. Diamond, "Polyreactive autoantibodies in systemic lupus erythematosus have pathogenic potential," Journal of Autoimmunity, vol. 33, pp. 270-274, 2009.

[2] K. Tenbrock, Y.-T. Juang, V. C. Kyttaris, and G. C. Tsokos, "Altered signal transduction in SLE T cells," Rheumatology, vol. 46, no. 10, pp. 1525-1530, 2007.

[3] D. T. Boumpas, B. J. Fessler, H. A. Austin III, J. E. Balow, J. H. Klippel, and M. D. Lockshin, "Systemic lupus erythematosus: emerging concepts-part 2: dermatologic and joint disease, the antiphospholipid antibody syndrome, pregnancy and hormonal therapy, morbidity and mortality, and pathogenesis," Annals of Internal Medicine, vol. 123, no. 1, pp. 42-53, 1995.

[4] E. V. Lourenco and C. A. La, "Cytokines in systemic lupus erythematosus," Current Molecular Medicine, vol. 9, pp. 242254, 2009.

[5] O. Kulkarni and H.-J. Anders, "Chemokines in lupus nephritis," Frontiers in Bioscience, vol. 13, no. 9, pp. 3312-3320, 2008.

[6] M. Linker-Israeli, R. J. Deans, D. J. Wallace, J. Prehn, T. OzeriChen, and J. R. Klinenberg, "Elevated levels of endogenous IL-6 in systemic lupus erythematosus: a putative role in pathogenesis," The Journal of Immunology, vol. 147, no. 1, pp. 117-123, 1991.
[7] J.-F. Viallard, J. L. Pellegrin, V. Ranchin, et al., "Th1 (IL2 , interferon- $\gamma($ IFN- $\gamma$ )) and Th2 (IL-10, IL-4) cytokine production by peripheral blood mononuclear cells (PBMC) from patients with systemic lupus erythematosus (SLE)," Clinical and Experimental Immunology, vol. 115, no. 1, pp. 189-195, 1999.

[8] E. Hagiwara, M. F. Gourley, S. Lee, and D. M. Klinman, "Disease severity in patients with systemic lupus erythematosus correlates with an increased ratio of interleukin10:interferon- $\gamma$-secreting cells in the peripheral blood," Arthritis and Rheumatism, vol. 39, no. 3, pp. 379-385, 1996.

[9] F. A. Houssiau, C. Lefebvre, M. Vanden Berghe, M. Lambert, J.-P. Devogelaer, and J.-C. Renauld, "Serum interleukin 10 titers in systemic lupus erythematosus reflect disease activity," Lupus, vol. 4, no. 5, pp. 393-395, 1995.

[10] L. Llorente, W. Zou, Y. Levy, et al., "Role of interleukin 10 in the B lymphocyte hyperactivity and autoantibody production of human systemic lupus erythematosus," Journal of Experimental Medicine, vol. 181, no. 3, pp. 839-844, 1995.

[11] S. Diehl and M. Rincón, "The two faces of IL-6 on Th1/Th2 differentiation," Molecular Immunology, vol. 39, no. 9, pp. 531-536, 2002.

[12] M. Al-Janadi, S. Al-Balla, A. Al-Dalaan, and S. Raziuddin, "Cytokine profile in systemic lupus erythematosus, rheumatoid arthritis, and other rheumatic diseases," Journal of Clinical Immunology, vol. 13, no. 1, pp. 58-67, 1993.

[13] A. Studnicka-Benke, G. Steiner, P. Petera, and J. S. Smolen, "Tumour necrosis factor $\alpha$ and its soluble receptors parallel clinical disease and autoimmune activity in systemic lupus erythematosus," British Journal of Rheumatology, vol. 35, no. 11, pp. 1067-1074, 1996.

[14] C. Gabay, N. Cakir, F. Moral, et al., "Circulating levels of tumor necrosis factor soluble receptors in systemic lupus erythematosus are significantly higher than in other rheumatic diseases and correlate with disease activity," Journal of Rheumatology, vol. 24, no. 2, pp. 303-308, 1997.

[15] R. A. Mageed and D. A. Isenberg, "Tumour necrosis factor $\alpha$ in systemic lupus erythematosus and anti-DNA autoantibody production," Lupus, vol. 11, no. 12, pp. 850-855, 2002.

[16] R. Cervera, M. A. Khamashta, J. Font, et al., "Systemic lupus erythematosus: clinical and immunologic patterns of disease expression in a cohort of 1,000 patients. The European Working Party on Systemic Lupus Erythematosus," Medicine, vol. 72, pp. 113-124, 1993.

[17] R. G. Lahita, "The role of sex hormones in systemic lupus erythematosus," Current Opinion in Rheumatology, vol. 11, no. 5, pp. 352-356, 1999.

[18] J. J. Michnovicz and H. L. Bradlow, "Altered estrogen metabolism and excretion in humans following consumption of indole-3-carbinol," Nutrition and Cancer, vol. 16, no. 1, pp. 59-66, 1991.

[19] R. G. Lahita, H. L. Bradlow, H. G. Kunkel, and J. Fishman, "Alterations of estrogen metabolism in systemic lupus erythematosus," Arthritis and Rheumatism, vol. 22, no. 11, pp. 1195-1198, 1979.

[20] A. Doria, L. Iaccarino, P. Sarzi-Puttini, et al., "Estrogens in pregnancy and systemic lupus erythematosus," Annals of the New York Academy of Sciences, vol. 1069, pp. 247-256, 2006.

[21] A. N. Baer and F. A. Green, "Estrogen metabolism in the (New Zealand black $\times$ New Zealand white) $\mathrm{F}_{1}$ murine model of systemic lupus erythematosus," Arthritis and Rheumatism, vol. 33, no. 1, pp. 107-112, 1990.

[22] R. G. Lahita, "Sex steroids and the rheumatic diseases," Arthritis and Rheumatism, vol. 28, no. 2, pp. 121-126, 1985. 
[23] K. R. Culwell, K. M. Curtis, and M. del Carmen Cravioto, "Safety of contraceptive method use among women with systemic lupus erythematosus: a systematic review," Obstetrics and Gynecology, vol. 114, no. 2, part 1, pp. 341-353, 2009.

[24] A. D. Askanase, "Estrogen therapy in systemic lupus erythematosus," Treatments in Endocrinology, vol. 3, no. 1, pp. 1926, 2004.

[25] J. P. Buyon, M. A. Petri, M. Y. Kim, et al., "The effect of combined estrogen and progesterone hormone replacement therapy on disease activity in systemic lupus erythematosus: a randomized trial," Annals of Internal Medicine, vol. 142, no. 12, pp. 953-962, 2005.

[26] J. Sánchez-Guerrero, M. González-Pérez, M. DurandCarbajal, et al., "Menopause hormonal therapy in women with systemic lupus erythematosus," Arthritis and Rheumatism, vol. 56, no. 9, pp. 3070-3079, 2007.

[27] C. C. Mok, C. S. Lau, C. T. K. Ho, et al., "Safety of hormonal replacement therapy in postmenopausal patients with systemic lupus erythematosus," Scandinavian Journal of Rheumatology, vol. 27, no. 5, pp. 342-346, 1998.

[28] R. L. Yung, "Mechanisms of lupus: the role of estrogens," Clinical and Experimental Rheumatology, vol. 17, no. 3, pp. 271-275, 1999.

[29] J. F. G. Cohen-Solal, V. Jeganathan, C. M. Grimaldi, E. Peeva, and B. Diamond, "Sex hormones and SLE: influencing the fate of autoreactive B Cells," Current Topics in Microbiology and Immunology, vol. 305, pp. 67-88, 2006.

[30] R. H. Straub, "The complex role of estrogens in inflammation," Endocrine Reviews, vol. 28, no. 5, pp. 521-574, 2007.

[31] G. L. Greene, P. Gilna, M. Waterfield, A. Baker, Y. Hort, and J. Shine, "Sequence and expression of human estrogen receptor complementary DNA," Science, vol. 231, pp. 11501154, 1986.

[32] S. Mosselman, J. Polman, and R. Dijkema, "ER $\beta$ : identification and characterization of a novel human estrogen receptor," FEBS Letters, vol. 392, no. 1, pp. 49-53, 1996.

[33] R. M. Evans, "The steroid and thyroid hormone receptor superfamily," Science, vol. 240, no. 4854, pp. 889-895, 1988.

[34] J. Matthews and J. A. Gustafsson, "Estrogen signaling: a subtle balance between ER $\alpha$ and ER $\beta$," Molecular Interventions, vol. 3, no. 5, pp. 281-292, 2003.

[35] J. T. Moore, D. D. McKee, K. Slentz-Kesler, et al., "Cloning and characterization of human estrogen receptor $\beta$ isoforms," Biochemical and Biophysical Research Communications, vol. 247, no. 1, pp. 75-78, 1998.

[36] C. E. Mason, F. J. Shu, C. Wang, et al., "Location analysis for the estrogen receptor- $\alpha$ reveals binding to diverse ERE sequences and widespread binding within repetitive DNA elements," Nucleic Acids Research, vol. 38, no. 7, pp. 23552368, 2010.

[37] M. Beato, P. Herrlich, and G. Schütz, "Steroid hormone receptors: many actors in search of a plot," Cell, vol. 83, no. 6, pp. 851-857, 1995.

[38] K. B. Horwitz, T. A. Jackson, D. L. Bain, J. K. Richer, G. S. Takimoto, and L. Tung, "Nuclear receptor coactivators and corepressors," Molecular Endocrinology, vol. 10, no. 10, pp. 1167-1177, 1996.

[39] K. C. Lee and W. L. Kraus, "Nuclear receptors, coactivators and chromatin: new approaches, new insights," Trends in Endocrinology and Metabolism, vol. 12, no. 5, pp. 191-197, 2001.

[40] L. P. Freedman, "Increasing the complexity of coactivation in nuclear receptor signaling," Cell, vol. 97, no. 1, pp. 5-8, 1999.
[41] A. P. Wolffe, "Chromatin remodeling regulated by steroid and nuclear receptors," Cell Research, vol. 7, no. 2, pp. 127-142, 1997.

[42] A. P. Wolffe and J. J. Hayes, "Chromatin disruption and modification," Nucleic Acids Research, vol. 27, no. 3, pp. 711720, 1999.

[43] G. Cerillo, A. Rees, N. Manchanda, et al., "The oestrogen receptor regulates $\mathrm{NF} \kappa \mathrm{B}$ and $\mathrm{AP}-1$ activity in a cell-specific manner," Journal of Steroid Biochemistry and Molecular Biology, vol. 67, no. 2, pp. 79-88, 1998.

[44] K. Paech, P. Webb, G. G. J. M. Kuiper, et al., "Differential ligand activation of estrogen receptors $\mathrm{ER} \alpha$ and $\operatorname{ERr} \beta$ at AP1 sites," Science, vol. 277, no. 5331, pp. 1508-1510, 1997.

[45] P. Webb, G. N. Lopez, R. M. Uht, and P. J. Kushner, "Tamoxifen activation of the estrogen receptor/AP-1 pathway: potential origin for the cell-specific estrogen-like effects of antiestrogens," Molecular Endocrinology, vol. 9, no. 4, pp. 443-456, 1995.

[46] L. I. McKay and J. A. Cidlowski, "Molecular control of immune/inflammatory responses: interactions between nuclear factor- $\kappa \mathrm{B}$ and steroid receptor-signaling pathways," Endocrine Reviews, vol. 20, no. 4, pp. 435-459, 1999.

[47] J. Pfeilschifter, R. Köditz, M. Pfohl, and H. Schatz, "Changes in proinflammatory cytokine activity after menopause," Endocrine Reviews, vol. 23, no. 1, pp. 90-119, 2002.

[48] S. Kato, H. Endoh, Y. Masuhiro, et al., "Activation of the estrogen receptor through phosphorylation by mitogenactivated protein kinase," Science, vol. 270, no. 5241, pp. 1491-1494, 1995.

[49] R. M. L. Zwijsen, E. Wientjens, R. Klompmaker, J. van der Sman, R. Bernards, and R.J.A.M. Michalides, "CDKindependent activation of estrogen receptor by cyclin D1," Cell, vol. 88, no. 3, pp. 405-415, 1997.

[50] S. Nilsson, S. Mäkelä, E. Treuter, et al., "Mechanisms of estrogen action," Physiological Reviews, vol. 81, no. 4, pp. 1535-1565, 2001.

[51] N. Picard, C. Charbonneau, M. Sanchez, et al., "Phosphorylation of activation function-1 regulates proteasomedependent nuclear mobility and E6-associated protein ubiquitin ligase recruitment to the estrogen receptor $\beta$," Molecular Endocrinology, vol. 22, no. 2, pp. 317-330, 2008.

[52] K. Sauve, J. Lepage, M. Sanchez, N. Heveker, and A. Tremblay, "Positive feedback activation of estrogen receptors by the CXCL12-CXCR4 pathway," Cancer Research, vol. 69, no. 14, pp. 5793-5800, 2009.

[53] A. Pedram, M. Razandi, and E. R. Levin, "Nature of functional estrogen receptors at the plasma membrane," Molecular Endocrinology, vol. 20, no. 9, pp. 1996-2009, 2006.

[54] L. Li, M. P. Haynes, and J. R. Bender, "Plasma membrane localization and function of the estrogen receptor $\alpha$ variant (ER46) in human endothelial cells," Proceedings of the National Academy of Sciences of the United States of America, vol. 100, no. 8, pp. 4807-4812, 2003.

[55] C. M. Doolan and B. J. Harvey, "A G $\alpha$ s protein-coupled membrane receptor, distinct from the classical oestrogen receptor, transduces rapid effects of oestradiol on $\left[\mathrm{Ca}^{+}\right]$in female rat distal colon," Molecular and Cellular Endocrinology, vol. 199, no. 1-2, pp. 87-103, 2003.

[56] M. Razandi, A. Pedram, G. L. Greene, and E. R. Levin, "Cell membrane and nuclear estrogen receptors (ERs) originate from a single transcript: studies of ER $\alpha$ and ER $\beta$ expressed in Chinese hamster ovary cells," Molecular Endocrinology, vol. 13, pp. 307-319, 1999. 
[57] R. X. Song, C. J. Barnes, Z. Zhang, Y. Bao, R. Kumar, and R.J. Santen, "The role of Shc and insulin-like growth factor 1 receptor in mediating the translocation of estrogen receptor $\alpha$ to the plasma membrane," Proceedings of the National Academy of Sciences of the United States of America, vol. 101, no. 7, pp. 2076-2081, 2004.

[58] F. Acconcia, P. Ascenzi, A. Bocedi, et al., "Palmitoylationdependent estrogen receptor $\alpha$ membrane localization: regulation by $17 \beta$-estradiol," Molecular Biology of the Cell, vol. 16, no. 1, pp. 231-237, 2005.

[59] P. Thomas, Y. Pang, E. J. Filardo, and J. Dong, "Identity of an estrogen membrane receptor coupled to a $G$ protein in human breast cancer cells," Endocrinology, vol. 146, no. 2, pp. 624-632, 2005.

[60] E. R. Prossnitz, J. B. Arterburn, H. O. Smith, T. I. Oprea, L. A. Sklar, and H. J. Hathaway, "Estrogen signaling through the transmembrane G protein-coupled receptor GPR30," Annual Review of Physiology, vol. 70, pp. 165-190, 2008.

[61] T. Simoncini, A. Hafezi-Moghadam, D. P. Brazil, K. Ley, W. W. Chin, and J. K. Liao, "Interaction of oestrogen receptor with the regulatory subunit of phosphatidylinositol-3-OH kinase," Nature, vol. 407, no. 6803, pp. 538-541, 2000.

[62] E. J. Filardo, J. A. Quinn, K. I. Bland, and A. R. Frackelton Jr., "Estrogen-induced activation of Erk-1 and Erk-2 requires the $G$ protein-coupled receptor homolog, GPR30, and occurs via trans-activation of the epidermal growth factor receptor through release of HB-EGF," Molecular Endocrinology, vol. 14, no. 10, pp. 1649-1660, 2000.

[63] C. M. Revankar, D. F. Cimino, L. A. Sklar, J. B. Arterburn, and E. R. Prossnitz, "A transmembrane intracellular estrogen receptor mediates rapid cell signaling," Science, vol. 307, no. 5715, pp. 1625-1630, 2005.

[64] G. B. Stefano and D. Peter, "Cell surface estrogen receptors coupled to cNOS mediate immune and vascular tissue regulation: therapeutic implications," Medical Science Monitor, vol. 7, pp. 1066-1074, 2001.

[65] W. P. M. Benten, A. Becker, H.-P. Schmitt-Wrede, and F. Wunderlich, "Developmental regulation of intracellular and surface androgen receptors in T cells," Steroids, vol. 67, no. 11, pp. 925-931, 2002.

[66] J. W. Simpkins, S.-H. Yang, S. N. Sarkar, and V. Pearce, "Estrogen actions on mitochondria-physiological and pathological implications," Molecular and Cellular Endocrinology, vol. 290, no. 1-2, pp. 51-59, 2008.

[67] K. Scheller and C. E. Sekeris, "The effects of steroid hormones on the transcription of genes encoding enzymes of oxidative phosphorylation," Experimental Physiology, vol. 88, no. 1, pp. 129-140, 2003.

[68] E. Bettini and A. Maggi, "Estrogen induction of cytochrome c oxidase subunit III in rat hippocampus," Journal of Neurochemistry, vol. 58, no. 5, pp. 1923-1929, 1992.

[69] C. M. Van Itallie and P. S. Dannies, "Estrogen induces accumulation of the mitochondrial ribonucleic acid for subunit II of cytochrome oxidase in pituitary tumor cells," Molecular Endocrinology, vol. 2, no. 4, pp. 332-337, 1988.

[70] J.-Q. Chen, P. R. Cammarata, C. P. Baines, and J. D. Yager, "Regulation of mitochondrial respiratory chain biogenesis by estrogens/estrogen receptors and physiological, pathological and pharmacological implications," Biochimica et Biophysica Acta, vol. 1793, no. 10, pp. 1540-1570, 2009.

[71] C. E. Sekeris, "The mitochondrial genome: a possible primary site of actin of steroid hormones," In Vivo, vol. 4, no. 5, pp. 317-320, 1990.
[72] C. V. Demonacos, N. Karayanni, E. Hatzoglou, C. Tsiriyiotis, D. A. Spandidos, and C. E. Sekeris, "Mitochondrial genes as sites of primary action of steroid hormones," Steroids, vol. 61, no. 4, pp. 226-232, 1996.

[73] J. Q. Chen, M. Eshete, W. L. Alworth, and J. D. Yager, "Binding of MCF-7 cell mitochondrial proteins and recombinant human estrogen receptors $\alpha$ and $\beta$ to human mitochondrial DNA estrogen response elements," Journal of Cellular Biochemistry, vol. 93, no. 2, pp. 358-373, 2004.

[74] J.-Q. Chen, P. A. Russo, C. Cooke, I. H. Russo, and J. Russo, "ER $\beta$ shifts from mitochondria to nucleus during estrogen-induced neoplastic transformation of human breast epithelial cells and is involved in estrogen-induced synthesis of mitochondrial respiratory chain proteins," Biochimica et Biophysica Acta, vol. 1773, no. 12, pp. 1732-1746, 2007.

[75] P. Gergely Jr., C. Grossman, B. Niland, et al., "Mitochondrial hyperpolarization and ATP depletion in patients with systemic lupus erythematosus," Arthritis and Rheumatism, vol. 46, no. 1, pp. 175-190, 2002.

[76] A. Perl, P. Gergely Jr., G. Nagy, A. Koncz, and K. Banki, "Mitochondrial hyperpolarization: a checkpoint of T-cell life, death and autoimmunity," Trends in Immunology, vol. 25, no. 7, pp. 360-367, 2004.

[77] Q. Li, J. Ward, S. Banerjee, and A. Perl, "Prominent changes in expression of $\mathrm{Ca}^{+}$fluxing, mitochondrial electron transport, and antioxidant pathway genes in peripheral blood lymphocytes of patients with systemic lupus erythematosus," Arthritis and Rheumatism, vol. 52, p. S617, 2005.

[78] T. Vyshkina, A. Sylvester, S. Sadiq, et al., "Association of common mitochondrial DNA variants with multiple sclerosis and systemic lupus erythematosus," Clinical Immunology, vol. 129, no. 1, pp. 31-35, 2008.

[79] G. C. Tsokos and G. M. Kammer, "Molecular aberrations in human systemic lupus erythematosus," Molecular Medicine Today, vol. 6, no. 11, pp. 418-424, 2000.

[80] A. B. Pernis, "Estrogen and CD4 ${ }^{+}$T cells," Current Opinion in Rheumatology, vol. 19, no. 5, pp. 414-420, 2007.

[81] D. Mevorach, S. Perrot, N. M. M. Buchanan, et al., "Appearance of systemic lupus erythematosus after thymectomy: four case reports and review of the literature," Lupus, vol. 4, no. 1, pp. 33-37, 1995.

[82] J. C. Gutierrez-Ramos, J. L. Andreu, Y. Revilla, E. Vinuela, and A. C. Martinez, "Recovery from autoimmunity of $\mathrm{MRL} / \mathrm{lpr}$ mice after infection with an interleukin-2/vaccinia recombinant virus," Nature, vol. 346, no. 6281, pp. 271-274, 1990.

[83] W. H. Stimson and I. C. Hunter, "Oestrogen-induced immunoregulation mediated through the thymus," Journal of Clinical and Laboratory Immunology, vol. 4, no. 1, pp. 27-33, 1980.

[84] M. R. Ryan, R. Shepherd, J. K. Leavey, et al., "An IL-7dependent rebound in thymic $\mathrm{T}$ cell output contributes to the bone loss induced by estrogen deficiency," Proceedings of the National Academy of Sciences of the United States of America, vol. 102, no. 46, pp. 16735-16740, 2005.

[85] J. E. Staples, T. A. Gasiewicz, N. C. Fiore, D. B. Lubahn, K. S. Korach, and A. E. Silverstone, "Estrogen receptor $\alpha$ is necessary in thymic development and estradiol-induced thymic alterations," The Journal of Immunology, vol. 163, no. 8, pp. 4168-4174, 1999. 
[86] J. H. M. Cohen, L. Danel, G. Cordier, S. Saez, and J. P. Revillard, "Sex steroid receptors in peripheral T cells: absence of androgen receptors and restriction of estrogen receptors to OKT8-positive cells," The Journal of Immunology, vol. 131, no. 6, pp. 2767-2771, 1983.

[87] R. Suenaga, M. J. Evans, K. Mitamura, V. Rider, and N. I. Abdou, "Peripheral blood T cells and monocytes and B cell lines derived from patients with lupus express estrogen receptor transcripts similar to those of normal cells," Journal of Rheumatology, vol. 25, no. 7, pp. 1305-1312, 1998.

[88] A. Maret, J. D. Coudert, L. Garidou, et al., "Estradiol enhances primary antigen-specific CD4 T cell responses and Th1 development in vivo. Essential role of estrogen receptor $\alpha$ expression in hematopoietic cells," European Journal of Immunology, vol. 33, no. 2, pp. 512-521, 2003.

[89] M. Bao, Y. Yang, H.-S. Jun, and J.-W. Yoon, "Molecular mechanisms for gender differences in susceptibility to T cellmediated autoimmune diabetes in nonobese diabetic mice," The Journal of Immunology, vol. 168, no. 10, pp. 5369-5375, 2002.

[90] J. P. Buyon, "The effects of pregnancy on autoimmune diseases," Journal of Leukocyte Biology, vol. 63, no. 3, pp. 281287, 1998.

[91] L. Krishnan, L. J. Guilbert, A. S. Russell, T. G. Wegmann, T. R. Mosmann, and M. Belosevic, "Pregnancy impairs resistance of C57BL/6 mice to Leishmania major infection and causes decreased antigen-specific IFN- $\gamma$ responses and increased production of T helper 2 cytokines," The Journal of Immunology, vol. 156, no. 2, pp. 644-652, 1996.

[92] M. L. Salem, “Estrogen, a double-edged sword: modulation of TH1- and TH2-mediated inflammations by differential regulation of TH1/TH2 cytokine production," Current Drug Targets: Inflammation and Allergy, vol. 3, no. 1, pp. 97-104, 2004.

[93] W. Gilmore, L. P. Weiner, and J. Correale, "Effect of estradiol on cytokine secretion by proteolipid protein-specific $\mathrm{T}$ cell clones isolated from multiple sclerosis patients and normal control subjects," The Journal of Immunology, vol. 158, no. 1, pp. 446-451, 1997.

[94] J. Correale, M. Arias, and W. Gilmore, "Steroid hormone regulation of cytokine secretion by proteolipid protein-specific $\mathrm{CD}^{+}{ }^{+} \mathrm{T}$ cell clones isolated from multiple sclerosis patients and normal control subjects," The Journal of Immunology, vol. 161, no. 7, pp. 3365-3374, 1998.

[95] Y. C. Q. Zang, J. B. Halder, J. Hong, V. M. Rivera, and J. Z. Zhang, "Regulatory effects of estriol on T cell migration and cytokine profile: inhibition of transcription factor NF- $\kappa \mathrm{B}$," Journal of Neuroimmunology, vol. 124, no. 1-2, pp. 106-114, 2002.

[96] K. C. Lambert, E. M. Curran, B. M. Judy, G. N. Milligan, D. B. Lubahn, and D. M. Estes, "Estrogen receptor $\alpha(\mathrm{ER} \alpha)$ deficiency in macrophages results in increased stimulation of $\mathrm{CD}^{+} \mathrm{T}$ cells while $17 \beta$-estradiol acts through ER $\alpha$ to increase IL- 4 and GATA-3 expression in $\mathrm{CD}^{+}{ }^{+} \mathrm{T}$ cells independent of antigen presentation," The Journal of Immunology, vol. 175, pp. 5716-5723, 2005.

[97] M. Kamada, M. Irahara, M. Maegawa, et al., "Transient increase in the levels of T-helper 1 cytokines in postmenopausal women and the effects of hormone replacement therapy," Gynecologic and Obstetric Investigation, vol. 52, no. 2, pp. 82-88, 2001.
[98] S. Kumru, A. Godekmerdan, and B. Yilmaz, "Immune effects of surgical menopause and estrogen replacement therapy in peri-menopausal women," Journal of Reproductive Immunology, vol. 63, no. 1, pp. 31-38, 2004.

[99] R. W. McMurray, K. Ndebele, K. J. Hardy, and J. K. Jenkins, "17- $\beta$-estradiol suppresses IL-2 and IL-2 receptor," Cytokine, vol. 14, no. 6, pp. 324-333, 2001.

[100] X. Xia, S. Zhang, Y. Yu, et al., "Effects of estrogen replacement therapy on estrogen receptor expression and immunoregulatory cytokine secretion in surgically induced menopausal women," Journal of Reproductive Immunology, vol. 81, pp. 8996, 2009.

[101] T. Suzuki, T. Shimizu, H. P. Yu, Y. C. Hsieh, M. A. Choudhry, and I. H. Chaudry, "Salutary effects of $17 \beta$-estradiol on T-cell signaling and cytokine production after trauma hemorrhage are mediated primarily via estrogen receptor- $\alpha$," American Journal of Physiology, vol. 292, pp. C2103-C2111, 2007.

[102] R. Segal, M. Dayan, H. Zinger, B. Habut, G. M. Shearer, and E. Mozes, "The effect of IL-12 on clinical and laboratory aspects of experimental SLE in young and aging mice," Experimental Gerontology, vol. 38, no. 6, pp. 661-668, 2003.

[103] M. L. Polan, A. Daniele, and A. Kuo, "Gonadal steroids modulate human monocyte interleukin-1 (IL-1) activity," Fertility and Sterility, vol. 49, no. 6, pp. 964-968, 1988.

[104] L. Steinman, "A brief history of $\mathrm{T}_{\mathrm{H}} 17$, the first major revision in the $\mathrm{T}_{\mathrm{H}} 1 / \mathrm{T}_{\mathrm{H}} 2$ hypothesis of $\mathrm{T}$ cell-mediated tissue damage," Nature Medicine, vol. 13, no. 2, pp. 139-145, 2007.

[105] A. Nalbandian, J. C. Crispin, and G. C. Tsokos, "Interleukin17 and systemic lupus erythematosus: current concepts," Clinical and Experimental Immunology, vol. 157, pp. 209215, 2009.

[106] C. Wang, B. Dehghani, Y. Li, L. J. Kaler, A. A. Vandenbark, and H. Offner, "Oestrogen modulates experimental autoimmune encephalomyelitis and interleukin-17 production via programmed death 1," Immunology, vol. 126, no. 3, pp. 329335, 2009.

[107] C. Wang, B. Dehghani, Y. Li, et al., "Membrane estrogen receptor regulates experimental autoimmune encephalomyelitis through upregulation of programmed death 1," The Journal of Immunology, vol. 182, pp. 3294-3303, 2009.

[108] A. Rogers and R. Eastell, "The effect of $17 \beta$-estradiol on production of cytokines in cultures of peripheral blood," Bone, vol. 29, no. 1, pp. 30-34, 2001.

[109] D. Rachon, J. Mysliwska, K. Suchecka-Rachon, J. Wieckiewicz, and A. Mysliwski, "Effects of oestrogen deprivation on interleukin- 6 production by peripheral blood mononuclear cells of postmenopausal women," Journal of Endocrinology, vol. 172, no. 2, pp. 387-395, 2002.

[110] D. Kube, C. Platzer, A. von Knethen, et al., "Isolation of the human interleukin 10 promoter. Characterization of the promoter activity in Burkitt's lymphoma cell lines," Cytokine, vol. 7, no. 1, pp. 1-7, 1995.

[111] H. S. Fox, B. L. Bond, and T. G. Parslow, "Estrogen regulates the IFN- $\gamma$ promoter," The Journal of Immunology, vol. 146, no. 12, pp. 4362-4367, 1991.

[112] P. A. Baeuerle and T. Henkel, "Function and activation of NF$\kappa \mathrm{B}$ in the immune system," Annual Review of Immunology, vol. 12, pp. 141-179, 1994.

[113] J. Liu and D. I. Beller, "Distinct pathways for NF- $\kappa$ B regulation are associated with aberrant macrophage IL-12 production in lupus- and diabetes-prone mouse strains," The Journal of Immunology, vol. 170, no. 9, pp. 4489-4496, 2003. 
[114] C. G. Katsiari and G. C. Tsokos, "Transcriptional repression of interleukin-2 in human systemic lupus erythematosus," Autoimmunity Reviews, vol. 5, no. 2, pp. 118-121, 2006.

[115] G. C. Tsokos, H. K. Wong, E. J. Enyedy, and M. P. Nambiar, "Immune cell signaling in lupus," Current Opinion in Rheumatology, vol. 12, no. 5, pp. 355-363, 2000.

[116] A. Rao, "NF-ATp: a transcription factor required for the coordinate induction of several cytokine genes," Immunology Today, vol. 15, no. 6, pp. 274-281, 1994.

[117] R. H. Schwartz, "Costimulation of T lymphocytes: The role of CD28, CTLA-4, and B7/BB1 in interleukin-2 production and immunotherapy," Cell, vol. 71, no. 7, pp. 1065-1068, 1992.

[118] H. K. Wong, G. M. Kammer, G. Dennis, and G. C. Tsokos, "Abnormal NF- $\kappa$ B activity in T lymphocytes from patients with systemic lupus erythematosus is associated with decreased p65-RelA protein expression," The Journal of Immunology, vol. 163, no. 3, pp. 1682-1689, 1999.

[119] P. Burgos, C. Metz, P. Bull, et al., "Increased expression of crel, from the NF- $\kappa \mathrm{B} /$ Rel family, in T cells from patients with systemic lupus erythematosus," Journal of Rheumatology, vol. 27, no. 1, pp. 116-127, 2000.

[120] T. M. Herndon, Y.-T. Juang, E. E. Solomou, S. W. Rothwell, M. F. Gourley, and G. C. Tsokos, "Direct transfer of p65 into $\mathrm{T}$ lymphocytes from systemic lupus erythematosus patients leads to increased levels of interleukin-2 promoter activity," Clinical Immunology, vol. 103, no. 2, pp. 145-153, 2002.

[121] O. Oikonomidou, P. G. Vlachoyiannopoulos, A. Kominakis, A. Kalofoutis, H. M. Moutsopoulos, and P. Moutsatsou, "Glucocorticoid receptor, nuclear factor $\kappa \mathrm{B}$, activator protein- 1 and C-jun N-terminal kinase in systemic lupus erythematosus patients," Neuroimmunomodulation, vol. 13, pp. 194-204, 2006.

[122] H. K. Wong, G. M. Kammer, N. Mishra, G. Dennis, and G. C. Tsokos, "Activator protein-1(AP-1) regulation in lymphocytes from patients with systemic lupus erythematosus," Arthritis and Rheumatism, vol. 42, p. S312, 1999.

[123] E. E. Solomou, Y.-T. Juang, M. F. Gourley, G. M. Kammer, and G. C. Tsokos, "Molecular basis of deficient IL2 production in $\mathrm{T}$ cells from patients with systemic lupus erythematosus," The Journal of Immunology, vol. 166, no. 6, pp. 4216-4222, 2001.

[124] V. C. Kyttaris, Y.-T. Juang, K. Tenbrock, A. Weinstein, and G. C. Tsokos, "Cyclic adenosine 5'-monophosphate response element modulator is responsible for the decreased expression of $\mathrm{c}$-fos, and activator protein-1 binding in $\mathrm{T}$ cells from patients with systemic lupus erythematosus," The Journal of Immunology, vol. 173, no. 5, pp. 3557-3563, 2004.

[125] S. Hirano, D. Furutama, and T. Hanafusa, "Physiologically high concentrations of $17 \beta$-estradiol enhance NF- $\kappa$ B activity in human T cells," American Journal of Physiology, vol. 292, no. 4, pp. R1465-R1471, 2007.

[126] B. Calippe, V. Douin-Echinard, M. Laffargue, et al., "Chronic estradiol administration in vivo promotes the proinflammatory response of macrophages to TLR4 activation: involvement of the phosphatidylinositol 3-kinase pathway," The Journal of Immunology, vol. 180, no. 12, pp. 7980-7988, 2008.

[127] D. Ding, H. Mehta, W. J. McCune, and M. J. Kaplan, "Aberrant phenotype and function of myeloid dendritic cells in systemic lupus erythematosus," The Journal of Immunology, vol. 177, no. 9, pp. 5878-5889, 2006.

[128] P. Decker, I. Kötter, R. Klein, B. Berner, and H.-G. Rammensee, "Monocyte-derived dendritic cells over-express CD86 in patients with systemic lupus erythematosus," Rheumatology, vol. 45, no. 9, pp. 1087-1095, 2006.
[129] V. Douin-Echinard, S. Laffont, C. Seillet, et al., "Estrogen receptor $\alpha$, but not $\beta$, is required for optimal dendritic cell differentiation and [corrected] CD40-induced cytokine production," The Journal of Immunology, vol. 180, pp. 36613669,2008

[130] N. Kanda, T. Tsuchida, and K. Tamaki, "Estrogen enhancement of anti-double-stranded DNA antibody and immunoglobulin $\mathrm{G}$ production in peripheral blood mononuclear cells from patients with systemic lupus erythematosus," Arthritis and Rheumatism, vol. 42, no. 2, pp. 328-337, 1999.

[131] P. R. Kramer, S. F. Kramer, and G. Guan, " 17 $\beta$-estradiol regulates cytokine release through modulation of CD16 expression in monocytes and monocyte-derived macrophages," Arthritis and Rheumatism, vol. 50, pp. 1967-1975, 2004.

[132] S. T. Pottratz, T. Bellido, H. Mocharla, D. Crabb, and S. C. Manolagas, "17 $\beta$-Estradiol inhibits expression of human interleukin- 6 promoter-reporter constructs by a receptordependent mechanism," The Journal of Clinical Investigation, vol. 93, pp. 944-950, 1994.

[133] S. Srivastava, M. N. Weitzmann, S. Cenci, F. P. Ross, S. Adler, and R. Pacifici, "Estrogen decreases TNF gene expression by blocking JNK activity and the resulting production of c-Jun and JunD," The Journal of Clinical Investigation, vol. 104, no. 4, pp. 503-513, 1999.

[134] S. A. Krieg, A. J. Krieg, and D. J. Shapiro, "A unique downstream estrogen responsive unit mediates estrogen induction of proteinase inhibitor-9, a cellular inhibitor of IL-1- $\beta$ converting enzyme (caspase 1)," Molecular Endocrinology, vol. 15, no. 11, pp. 1971-1982, 2001.

[135] M. Cutolo, P. Montagna, R. Brizzolara, et al., "Sex hormones modulate the effects of Leflunomide on cytokine production by cultures of differentiated monocyte/macrophages and synovial macrophages from rheumatoid arthritis patients," Journal of Autoimmunity, vol. 32, no. 3-4, pp. 254-260, 2009.

[136] M. J. Evans, S. MacLaughlin, R. D. Marvin, and N. I. Abdou, "Estrogen decreases in vitro apoptosis of peripheral blood mononuclear cells from women with normal menstrual cycles and decreases TNF- $\alpha$ production in SLE but not in normal cultures," Clinical Immunology and Immunopathology, vol. 82, no. 3, pp. 258-262, 1997.

[137] V. Rider, R. T. Foster, M. Evans, R. Suenaga, and N. I. Abdou, "Gender differences in autoimmune diseases: estrogen increases calcineurin expression in systemic lupus erythematosus," Clinical Immunology and Immunopathology, vol. 89, no. 2, pp. 171-180, 1998.

[138] J. Liu, J. D. Farmer Jr., W. S. Lane, J. Friedman, I. Weissman, and S. L. Schreiber, "Calcineurin is a common target of cyclophilin-cyclosporin A and FKBP-FK506 complexes," Cell, vol. 66, no. 4, pp. 807-815, 1991.

[139] B. E. Bierer, G. Hollander, D. Fruman, and S. J. Burakoff, "Cyclosporin A and FK506: molecular mechanisms of immunosuppression and probes for transplantation biology," Current Opinion in Immunology, vol. 5, no. 5, pp. 763773, 1993.

[140] J. Liu, N. Koyano-Nakagawa, Y. Amasaki, et al., "Calcineurindependent nuclear translocation of a murine transcription factor NFATx: molecular cloning and functional characterization," Molecular Biology of the Cell, vol. 8, no. 1, pp. 157170, 1997.

[141] J. Jain, P. G. McCaffrey, Z. Miner, et al., "The Tcell transcription factor NFATp is a substrate for calcineurin and interacts with Fos and Jun," Nature, vol. 365, pp. 352-355, 1993. 
[142] A. V. Tsytsykova, E. N. Tsitsikov, and R. S. Geha, "The CD40L promoter contains nuclear factor of activated T cellsbinding motifs which require AP-1 binding for activation of transcription," Journal of Biological Chemistry, vol. 271, no. 7, pp. 3763-3770, 1996.

[143] M. K. Crow and K. A. Kirou, "Regulation of CD40 ligand expression in systemic lupus erythematosus," Current Opinion in Rheumatology, vol. 13, no. 5, pp. 361-369, 2001.

[144] A. Desai-Mehta, L. Lu, R. Ramsey-Goldman, and S. K. Datta, "Hyperexpression of CD40 ligand by B and T cells in human lupus and its role in pathogenic autoantibody production," The Journal of Clinical Investigation, vol. 97, no. 9, pp. 20632073, 1996.

[145] J. Yazdany and J. Davis, "The role of CD40 ligand in systemic lupus erythematosus," Lupus, vol. 13, no. 5, pp. 377-380, 2004.

[146] D. Thanos and T. Maniatis, "NF- $\kappa$ B: a lesson in family values," Cell, vol. 80, no. 4, pp. 529-532, 1995.

[147] V. Rider, S. Jones, M. Evans, H. Bassiri, Z. Afsar, and N. I. Abdou, "Estrogen increases CD40 ligand expression in T cells from women with systemic lupus erythematosus," Journal of Rheumatology, vol. 28, no. 12, pp. 2644-2649, 2001.

[148] N. I. Abdou, V. Rider, C. Greenwell, X. Li, and B. F. Kimler, "Fulvestrant (Faslodex), an estrogen selective receptor downregulator, in therapy of women with systemic lupus erythematosus. Clinical, serologic, bone density, and $\mathrm{T}$ cell activation marker studies: a double-blind placebo-controlled trial," Journal of Rheumatology, vol. 35, no. 5, pp. 797-803, 2008.

[149] D. Verthelyi, M. Petri, M. Ylamus, and D. M. Klinman, "Disassociation of sex hormone levels and cytokine production in SLE patients," Lupus, vol. 10, no. 5, pp. 352-358, 2001.

[150] A. Doria, A. Ghirardello, L. Iaccarino, et al., "Pregnancy, cytokines, and disease activity in systemic lupus erythematosus," Arthritis Care and Research, vol. 51, no. 6, pp. 989-995, 2004.

[151] H. M. Lee, T. Mima, H. Sugino, et al., "Interactions among type I and type II interferon, tumor necrosis factor, and $\beta$-estradiol in the regulation of immune response-related gene expressions in systemic lupus erythematosus," Arthritis Research \& Therapy, vol. 11, p. R1, 2009.

[152] J. B. Howie and B. J. Helyer, "Autoimmune disease in mice," Annals of the New York Academy of Sciences, vol. 124, no. 1, pp. 167-177, 1965.

[153] J. B. Howie and B. J. Helyer, "The immunology and pathology of NZB mice," Advances in Immunology, vol. 9, pp. 215-266, 1968.

[154] Z. M. Sthoeger, Z. Bentwich, H. Zinger, and E. Mozes, "The beneficial effect of the estrogen antagonist, tamoxifen, on experimental systemic lupus erythematosus," Journal of Rheumatology, vol. 21, no. 12, pp. 2231-2238, 1994.

[155] M. Dayan, H. Zinger, F. Kalush, et al., "The beneficial effects of treatment with tamoxifen and anti-oestradiol antibody on experimental systemic lupus erythematosus are associated with cytokine modulations," Immunology, vol. 90, no. 1, pp. 101-108, 1997.

[156] K. B. Elbourne, D. Keisler, and R. W. McMurray, "Differential effects of estrogen and prolactin on autoimmune disease in the NZB/NZW F1 mouse model of systemic lupus erythematosus," Lupus, vol. 7, no. 6, pp. 420-427, 1998.

[157] S. H. Zuckerman, S. E. Ahmari, N. Bryan-Poole, G. F. Evans, L. Short, and A. L. Glasebrook, "Estriol: a potent regulator of TNF and IL-6 expression in a murine model of endotoxemia," Inflammation, vol. 20, no. 6, pp. 581-597, 1996.
[158] J. J. A. M. Weusten, M. A. Blankenstein, F. H. J. GmeligMeyling, H. J. Schuurman, L. Kater, and J. H. Thijssen, "Presence of oestrogen receptors in human blood mononuclear cells and thymocytes," Acta Endocrinologica, vol. 112, no. 3, pp. 409-414, 1986.

[159] R. H. Kelly and F. T. Vertosick Jr., "Systemic lupus erythematosus: a role for anti-receptor antibodies?" Medical Hypotheses, vol. 20, no. 1, pp. 95-101, 1986.

[160] B. H. Athreya, J. H. Rafferty, G. S. Sehgal, and R. G. Lahita, "Adenohypophyseal and sex hormones in pediatric rheumatic diseases," Journal of Rheumatology, vol. 20, no. 4, pp. 725-730, 1993.

[161] R. Suenaga, K. Mitamura, M. J. Evans, and N. I. Abdou, "Binding affinity and quantity of estrogen receptor in peripheral blood monocytes of patients with systemic lupus erythematosus," Lupus, vol. 5, no. 3, pp. 227-231, 1996.

[162] S. Feng, "Estrogen receptor content of peripheral blood lymphocytes in patients with systemic lupus erythematosus," Zhonghua Yi Xue Za Zhi, vol. 71, no. 1, pp. 1-2, 1991.

[163] K. B. Wilson, M. Evans, and N. I. Abdou, "Presence of a variant form of the estrogen receptor in peripheral blood mononuclear cells from normal individuals and lupus patients," Journal of Reproductive Immunology, vol. 31, no. 3, pp. 199-208, 1996.

[164] E. N. Kassi, P. G. Vlachoyiannopoulos, H. M. Moutsopoulos, C. E. Sekeris, and P. Moutsatsou, "Molecular analysis of estrogen receptor $\alpha$ and $\beta$ in lupus patients," European Journal of Clinical Investigation, vol. 31, no. 1, pp. 86-93, 2001.

[165] E. Enmark, M. Pelto-Huikko, K. Grandien, et al., "Human estrogen receptor $\beta$-gene structure, chromosomal localization, and expression pattern," Journal of Clinical Endocrinology and Metabolism, vol. 82, no. 12, pp. 4258-4265, 1997.

[166] K. L. Phiel, R. A. Henderson, S. J. Adelman, and M. M. Elloso, "Differential estrogen receptor gene expression in human peripheral blood mononuclear cell populations," Immunology Letters, vol. 97, no. 1, pp. 107-113, 2005.

[167] A. Inui, H. Ogasawara, T. Naito, et al., "Estrogen receptor expression by peripheral blood mononuclear cells of patients with systemic lupus erythematosus," Clinical Rheumatology, vol. 26, no. 10, pp. 1675-1678, 2007.

[168] V. Rider, X. Li, G. Peterson, J. Dawson, B. F. Kimler, and N. I. Abdou, "Differential expression of estrogen receptors in women with systemic lupus erythematosus," Journal of Rheumatology, vol. 33, no. 6, pp. 1093-1101, 2006.

[169] M. Saceda, R. K. Lindsey, H. Solomon, S. V. Angeloni, and M. B. Martin, "Estradiol regulates estrogen receptor mRNA stability," Journal of Steroid Biochemistry and Molecular Biology, vol. 66, no. 3, pp. 113-120, 1998.

[170] C. B. Foster, T. Lehrnbecher, F. Mol, et al., "Host defense molecule polymorphisms influence the risk for immunemediated complications in chronic granulomatous disease," The Journal of Clinical Investigation, vol. 102, no. 12, pp. 2146-2155, 1998.

[171] E. Kassi, P. G. Vlachoyiannopoulos, A. Kominakis, H. Kiaris, H. M. Moutsopoulos, and P. Moutsatsou, "Estrogen receptor $\alpha$ gene polymorphism and systemic lupus erythematosus: a possible risk?" Lupus, vol. 14, no. 5, pp. 391-398, 2005.

[172] M. Johansson, L. Ärlestig, B. Möller, T. Smedby, and S. Rantapää-Dahlqvist, "Oestrogen receptor $\alpha$ gene polymorphisms in systemic lupus erythematosus," Annals of the Rheumatic Diseases, vol. 64, no. 11, pp. 1611-1617, 2005. 
[173] Y. J. Lee, K. S. Shin, S. W. Kang, et al., "Association of the oestrogen receptor $\alpha$ gene polymorphisms with disease onset in systematic lupus erythematosus," Annals of the Rheumatic Diseases, vol. 63, no. 10, pp. 1244-1249, 2004.

[174] Z.-H. Liu, Z.-H. Cheng, R.-J. Gong, H. Liu, D. Liu, and L.-S. $\mathrm{Li}$, "Sex differences in estrogen receptor gene polymorphism and its association with lupus nephritis in Chinese," Nephron, vol. 90, no. 2, pp. 174-180, 2002.

[175] Z.-M. Lu, Z.-E. Wang, Y.-Q. Liu, et al., "Association of estrogen receptor $\alpha$ gene polymorphisms with cytokine genes expression in systemic lupus erythematosus," Croatian Medical Journal, vol. 50, no. 2, pp. 117-123, 2009.

[176] J. L. Svenson, J. EuDaly, P. Ruiz, K. S. Korach, and G. S. Gilkeson, "Impact of estrogen receptor deficiency on disease expression in the NZM2410 lupus prone mouse," Clinical Immunology, vol. 128, no. 2, pp. 259-268, 2008. 


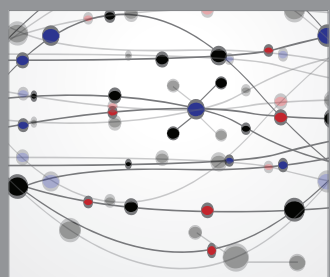

The Scientific World Journal
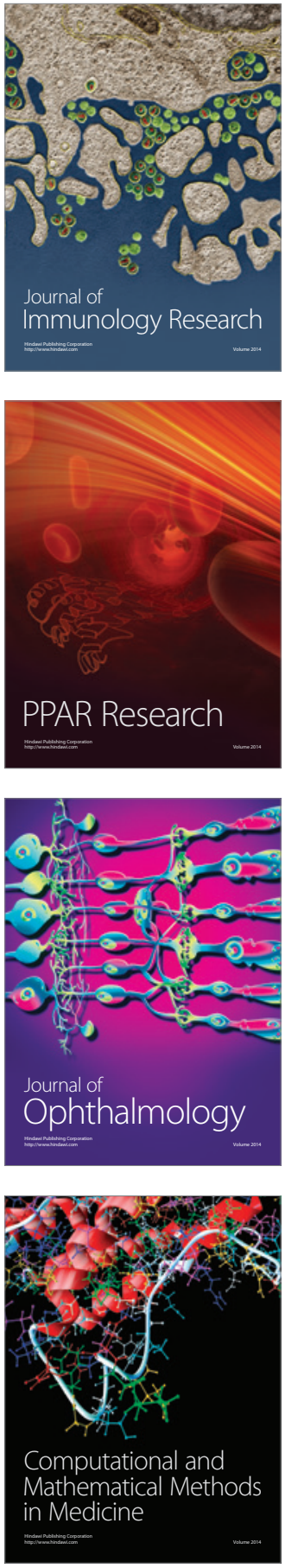

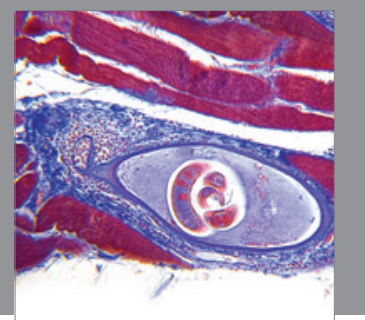

Gastroenterology

Research and Practice
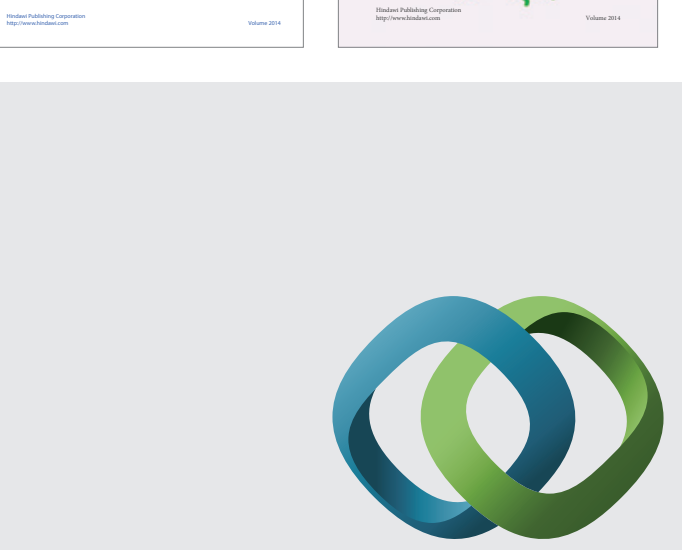

\section{Hindawi}

Submit your manuscripts at

http://www.hindawi.com
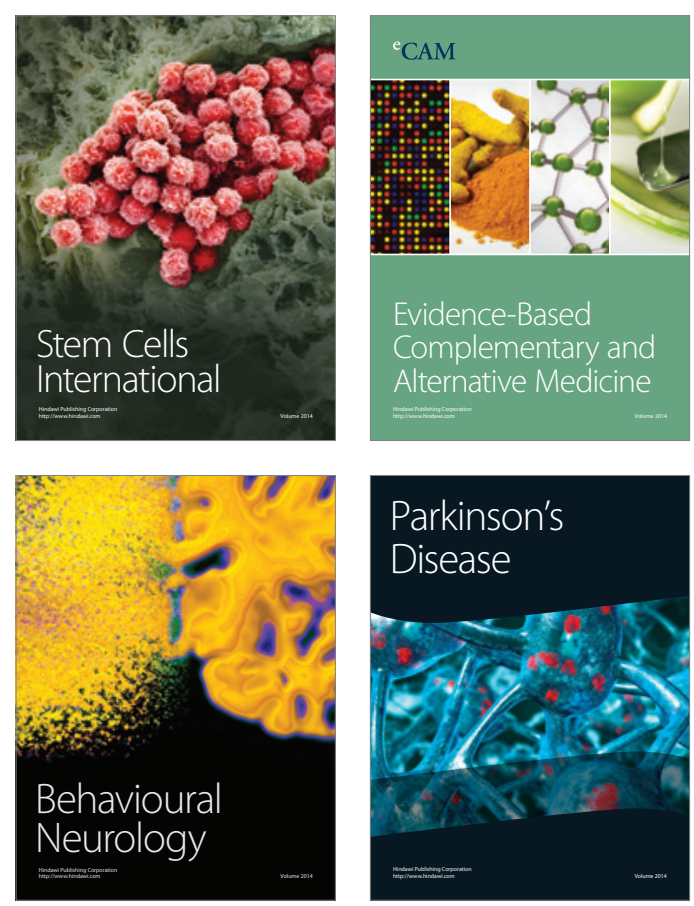

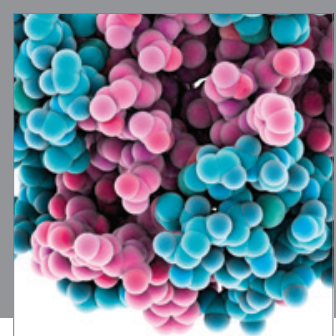

Journal of
Diabetes Research

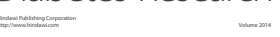

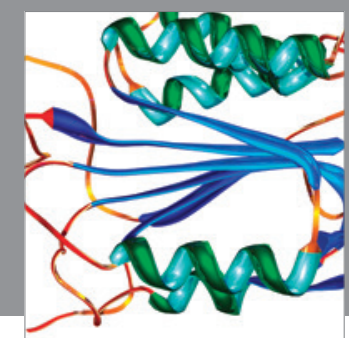

Disease Markers
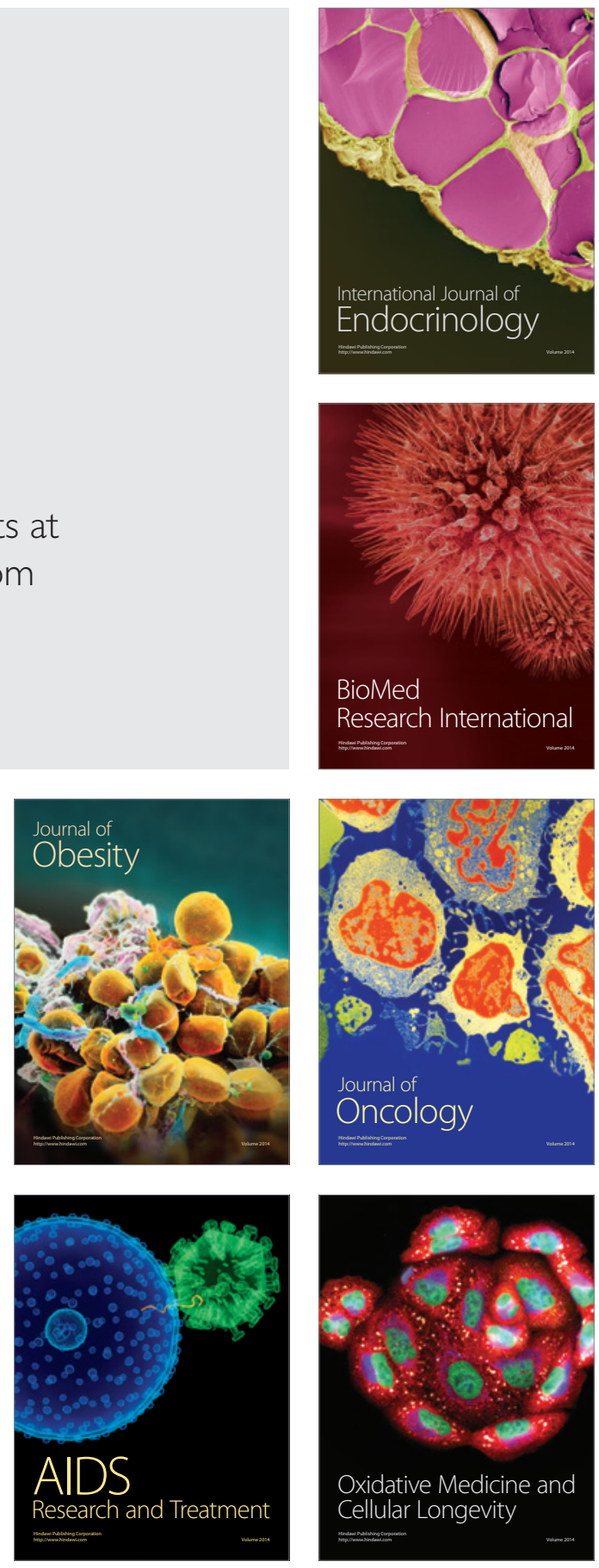